\title{
ANALISIS KONJUNGSI SHITAGATTE DAN YUE NI DALAM WEBSITE SURAT KABAR BAHASA JEPANG ASAHI.COM
}

\author{
Felicia \\ Japanese Department, Faculty of Language and Culture, Bina Nusantara University, \\ Jln. Kemanggisan Ilir III No. 45, Kemanggisan/Palmerah, Jakarta Barat 11480, \\ fbudihardja@binus.edu
}

\begin{abstract}
In studying the Japanese language there are many things that must be understood such as verbs, particles, adjectives and conjunctions. From existing various conjunctions, the author conducted an analysis of the conjunctions yue ni and shitagatte which has the same meaning but different in its use. The research method used was literature research method is to retrieve data from the Japanese newspaper website asahi.com. The purpose of this study is to investigate the function of conjunctions yue ni and shitagatte and know when to use shitagatte and when to use yue ni. After conducting an analysis of the 3 articles in which contains shitagatte and 3 articles in which contains yue ni, the authors conclude that the sentence after shitagatte only emphasize on the effect or outcome of the sentence before shitagatte, while on sentences after yue ni, in addition to a result or the results also contained elements of desire.
\end{abstract}

Keywords: conjuctions, shitagatte, yue ni, causal, outcome

\begin{abstract}
ABSTRAK
Dalam mempelajari bahasa Jepang ada banyak hal yang harus dipahami diantaranya kata kerja, partikel, kata sifat dan konjungsi. Dari bermacam-macam konjungsi yang ada penulis melakukan analisis terhadap konjungsi shitagatte dan yue ni yang memiliki makna yang sama tetapi berbeda dalam penggunaannya. Metode penelitian yang digunakan adalah metode penelitian pustaka yaitu dengan mengambil data dari website surat kabar bahasa Jepang asahi.com. Tujuan dari penelitian ini adalah untuk mengetahui fungsi dari konjungsi shitagatte dan yue ni serta mengetahui kapan harus menggunakan konjungsi shitagatte dan kapan harus menggunakan konjungsi yue ni. Setelah melakukan analisis terhadap 3 artikel yang didalamnya terdapan konjungsi shitagatte dan 3 artikel yang didalamnya terdapat konjungsi yue ni, penulis menyimpulkan bahwa kalimat setelah konjungsi shitagatte hanya menekankan pada akibat atau hasil dari kalimat sebelum konjungsi shitagatte, sedangkan kalimat setelah konjungsi yue ni, selain berupa akibat atau hasil juga terdapat unsur keinginan.
\end{abstract}

Kata kunci: konjungsi, shitagatte, yue ni, sebab, akibat 


\section{PENDAHULUAN}

Dalam mempelajari Bahasa Jepang ada banyak hal yang harus dipahami diantaranya kata kerja (動詞) yang memiliki banyak sekali perubahan, partikel (助詞) yang terdiri dari bermacammacam partikel, kata sifat (形容詞) yang terdiri dari kata sifat i dan kata sifat na, konjungsi (接続詞) yang memiliki kemiripan makna. Dari bermacam-macam konjungsi yang ada, penulis melakukan analisis fungsi konjungsi したがって dan ゆえに karena konjungsi ini dipelajari dalam bahasa Jepang tingkat lanjut.

Metode penelitian yang dipakai adalah penelitian pustaka dengan mengumpulkan korpus data dari website surat kabar berbahasa Jepang asahi.com. Alasan penulis menggunakan data dari surat kabar berbahasa Jepang asahi.com adalah karena したがって dan ゆえに merupakan konjungsi yang digunakan dalam bahasa tulisan,salah satunya adalah tulisan dalam artikel surat kabar.

Tujuan penelitian ini adalah untuk mengetahui fungsi dari したがって dan ゆえに yang memiliki makna yang hampir sama sehingga pembaca dapat mengetahui kapan harus menggunakan $し$ たがって dan kapan harus menggunakan ゆえに

\section{METODOLOGI}

Dalam penelitian ini metode yang digunakan penulis terdiri atas dua metode, yaitu metode deskriptif dan metode kepustakaan. Metode deskriptif adalah metode dengan cara kerja membahas suatu masalah dengan menata dan mengklasifikasikan serta memberi penjelasan tentang gejala-gejala yang tampak pada data tanpa melakukan pengujian. Dan yang dimaksud dengan metode kepustakaan yaitu cara pengumpulan data yang dilakukan terhadap sejumlah naskah tertulis yang merupakan sumber data. Dalam penelitian ini metode deskriptif dilakukan pada tahap penelitian data sedangkan metode kepustakaan dilakukan pada tahap pengumpulan data.

\section{HASIL DAN PEMBAHASAN}

\section{Landasan Teori}

\section{Konjungsi}

Konjungsi digunakan untuk menghubungkan antara kalimat yang satu dengan kalimat yang lain. Konjungsi memegang peranan penting dalam proses pembuatan kaliamat baik kalimat yang digunakan secara lisan maupun tulisan. Berikut ini adalah pembagian fungsi dari konjungsi dalam bahasa Jepang yang dibagi berdasarkan hubungan antar kalimat.

1. 順接

Terdiri dari :

a. Bentuk yang menyatakan sebab, alasan, akibat. Contohnya adalah :

だから、それで（で）、そのために（そのため）、そこで、その結果、したがって、 ゆえに、そのゆえに

b. Bentuk syarat. Contohnya adalah :

すると、それなら（だったら）、それでは（それじや、では、じや） 
2. 理由を述べ

Terdiri dari :

なぜなら、なぜかというと、というのは、だって

3. 逆説

Terdiri dari :

しかし、けれども、だけど、が、でも、しかしながら、それなのに、なのに、にも かかわらず、ところが、それが、とはいえ、とはいうものの

4. 言い換え・例示

Terdiri dari :

つまり、すなわち、要するに、例えば、いわば

5. 並列・添加

Terdiri dari :

そして、それから、それに、また、そのうえ、しかも、おまけに、さらに、それば かりか、そればかりでなく、のみならず、それどころか、および、ならびに、かつ

6. 補足

Terdiri dari :

なお、ただし、ただ、もつとも、ちなみに

7. 選択 (pilihan)

Terdiri dari :

または、それとも、あるいは、ないしは、もしくは

8. 対比

Terdiri dari :

一方、逆に、反対に

9. 転換

Terdiri dari :

ところで、それでは（それじや、では、じゃ）、さて、話が変わりますが、それは そうと、それはさておき

10. 総括

Terdiri dari :

このように、以上のように、こうして

Karena konjungsi したがって dan ゆえに termasuk ke dalam fungsi 順接, maka berikut ini adalah penjelasan rinci mengenai 順接.

Bentuk 順接 yang menyatakan sebab, alasan pada dasarnya digunakan untuk menghubungkan dua kalimat dimana kalimat tersebut merupakan kalimat majemuk yang memiliki hubungan sebab akibat.. Bentuk yang paling dasar dari 順接 adalah だから, それで dan そのために. Kalimat setelah だから dapat berupa kenyataan, pertimbangan dari pembicara, perintah, permohonan, keinginan dan bermacam-macam ungkapan lainnya. Kalimat setelah それで dan そのために biasanya berupa kenyataan dan tidak dapat menggunakan kalimat yang menyatakan penilaian, perintah, permohonan dan keinginan. Contoh :

1. 昨日は体調が悪かった。 けなかった。（事実）

Kemarin saya tidak enak badan. Oleh karena itu, saya tidak dapat pergi untuk bekerja paruh waktu.

2.もうすぐクリスマスだ。\{○だから/×それで／×そのために んでいるだろう。（判断）

Sebentar lagi hari natal. Oleh karena itu restoran pasti penuh. 


\section{3．体調が悪いんです。\{○だから/×それで／×そのために\} 早退させてください。 (依頼) \\ Saya tidak enak badan. Oleh karena itu tolong ijinkan saya untuk pulang lebih awal.}

Pada kalimat pertama,だから、それで、そのために dapat digunakan karena kalimat setelah だから、それで dan そのために adalah kalimat yang berupa kenyataan (pada kenyataannya saya tidak dapat pergi untuk bekerja paruh waktu). Pada kalimat ke dua konjungsi yang dapat digunakan hanya だから karena kalimat setelah konjungsi だから adalah kalimat yang menyatakan penilaian atau pertimbangan (penilaian bahwa mungkin pada saat hari natal restoran akan penuh). Pada kalimat ke tiga konjungsi yang dapat digunakan hanya だから karena kalimat setelah konjungsi だから adalah kalimat yang menyatakan permohonan (permohonan untuk pulang lebih cepat).

それで dapat disingkat menjadi で dan そのために dapat dsingkat menjadi そのため. Baik それで、 で、そのために dan ため dapat digunakan dalam kalimat.

したがって dan ゆえに merupakan konjungsi yang digunakan untuk hal-hal yang berhubungan dengan penjelasan secara teoritis. Kalimat sebelum konjungsi したがって dan ゆえに adalah kalimat yang berupa sebab atau alasan, sedangkan kalimat setelah konjungsi したがって dan ゆえに pada umumnya adalah kalimat yang memiliki makna penilaian dari si pembicara sebagai suatu akibat dari kalimat sebelumnya. Contoh :

1. 外部から人の入った形跡はない。したがって、内部の者の犯行としか考えられない。 Tidak ditemukan bukti bahwa ada orang luar yang masuk. Oleh karena itu, dapat disimpulkan bahwa pelakunya adalah orang dalam.

2. 角 $\mathrm{A}$ は直角、角 $\mathrm{B}$ は 30 度である。ゆえに、角 C は 60 度である。 Sudut A adalah sudut siku-siku, sudut B 30 derajat. Oleh karena itu, sudut C adalah 60 derajat.

Karena mengambil korpus data dari website surat kabar bahasa Jepang asahi.com, maka berikut ini adalah teori bahasa Jepang Koran (walaupun sudah ditulis dalam website tetapi ada beberapa hal mengenai dasar-dasar penulisan surat kabar yang tetap digunakan di dalam website surat kabar).

\section{Bahasa Jepang Surat Kabar}

Dalam bahasa Jepang surat kabar, banyak terdapat singkatan dan banyak terjadi penghilangan partikel dan kata kerja. Menurut Katayama (1995:7), ada beberapa hal yang perlu diperhatikan dalam bahasa Jepang surat kabar, yaitu :

\section{Terjadinya penyingkatan kata dan penghilangan partikel serta kata kerja.}

Penyingkatan kata dan penghilangan partikel serta kata kerja berlaku utuk judul artikel maupun isi artikel iti sendiri. Khusus untuk judul artikel, dalam AJALT (1991: 6) ditulis bahwa ada beberapa hal yang perlu diperhatikan dalam penulisan judul artikel, yaitu:

\section{Partikel}

- Penghilangan partikel dapat dilakukan karena walaupun partikel tidak ada, tetapi judul artikel tersebut masih dapat mudah dimengerti.

- Tetapi ada partikel yang mempunyai fungsi tertentu yang tidak dapat dihilangkan, seperti di bawah ini : 
- Partikel に

ketika disambung dengan なる

ketika menunjukkan waktu

ketika diletakkan sebelum kata kerja

- Partikel $\sim$

Ketika menunjukkan arah atau kondisi yang akan datang

Contoh : 高品位テレビ開発へ。(AJALT, 1991: 61)

'Menuju ke arah siaran televisi bermutu'

- Partikel で

Ketika menunjukkan alasan, tempat atau topic

Contoh : コーヒー生豆、内外で、急勝 (AJALT, 1991: 61)

'Orang dari dalam dan luar negri berbondong-bondong untuk memperoleh biji kopi mentah’

- Partikel が・も

Ketika ingin memberikan penekanan pada kata di depannya

Contoh : 需要増え在庫もていをつく

'Permintaan bertambah, persediaan habis'

- Partikel を

Banyak judul artikel yang diakhiri dengan partikel を untuk menunjukkan arti perrmintaan, permohonan

Contoh : 日本は援助拡大总 (AJALT, 1991: 61)

'Memohon bantuan besar kepada Jepang'

\section{Kata kerja}

Kata kerja yang dapat dihilangkan adalah :

・ 寸る、した、している、なる、なった

- Kata kerja yang menyambung pada nomina dan idiom juga dapat dihilangkan

Contoh : 重点《を置く》

'Menitikberatkan'

Kata kerja yang tidak dapat dihilangkan adalah :

- Kata kerja dari bahasa Jepang murni

Contoh : ていをつく

'mendasar'

- Kata kerja bentuk negatif yang diakhiri dengan 「ず」

Hal yang perlu diperhatikan adalah walaupun isi artikel menunjukkan hal yang terjadi dimasa mendatang, tetapi judul artikel tetap menggunakan bentuk sekarang.

\section{Hal lainnya yang perlu diperhatikan}

- Kata yang ditulis dengan huruf kecil: waktu, tempat, sub judul, penulis artikel, penerbit 1.3.2) Jumlah ditulis dengan angka romawi. Tetapi jumlah dalam isi artikel ditulis dengan kanji

Contoh jumlah dalam judul artikel :

過剩販促自肃 42,8\%に (AJALT, 1991: 63)

Contoh jumlah dalam isi artikel :

土二月前半は前年比三 $0 \%$ 強と好調だが、例年後半伸び悩むためだ。 (AJALT, 1991: 63) 
• Ketika menghilangkan partikel は、が、dan を maka digunakan koma (,) atau membuka ruang diantara kata berikutnya

Contoh : トヨタ、8 年ぶりシェア低下。(AJALT, 1991: 63)

Kalimat lengkapnya : トヨタは 8 年ぶりにシェアが低下しそうだ。

Contoh penghilangan partikel dan kata kerja dalam judul artikel :

寒さ緩んで節分

'Ketika dingin sudah mereda maka dimulailah festival'

Pada kalimat di atas terdapat penghilangan partikel が dan kata kerja 来た.

Kalimat lengkapnya :

寒さが緩んで節分が来た

Partikel が yang mengacu pada subjek kalimat sering dihilangkan dalam setiap judul artikel, begitu pula dengan 来た karena kata kerja dan kata sifat sering dihilangkan.

\section{Tidak menggunakan kata ganti 「彼」dan「彼女」}

Alasan tidak digunakannya kata ganti tersebut adalah untuk menghindari munculnya kesalahan ketika jurnalis menghapus informasi atau menambah informasi baru dalam artikel yang telah ditulis sebelumnya sebagai sebuah cerita yang diberitakan.「彼」dan「彼女」 biasanya menunjuk pada orang yang telah disebutkan sebelumnya. Jadi dengan tidak menggunakan kata ganti tersebut akan mengurangi gangguan atau masalah dari proses pengecekan kata ganti setiap kali ada penambahan atau penghapusan yang dilakukan oleh jurnalis tersebut.

\section{Analisis Fungsi したがって}

【質問】本社とタイの現地子会社の給与水準に差があるので、本社から差額の補てんを受け ますが、この部分は日本の所得税を支払うのですか。

'Tanya: Karena adanya perbedaan standar pembayaran antara kantor pusat dan kantor cabang yang berada di Thailand, maka harus menerima perbedaan kompensasi dari kantor pusat. Dalam hal ini apakah harus membayar pajak penghasilan untuk Jepang?’

【答え】国内源泉得は、国内において行う勤務に基づくものをいいます。あなたの場合は夕 イでの勤務に基づくものですので、国内源泉所得に該当しません。したがって、本社は源泉 徵収をしません。ただし、この差額補てん分を含めてタイの所得税を支払う必要があります。 'Jawab: Pendapatan dalam negri berasal dari hasil kerja yang dilakukan di dalam negri. Untuk kasus anda, anda tidak perlu melakukan pembayaran pajak penghasilan untuk Jepang, karena basis pekerjaan anda berada di Thailand. Oleh sebab itu, perusahaan pusat tidak akan melakukan penarikan pembayaran. Akan tetapi, anda harus membayar pajak penghasilan di Thailand beserta dengan perbedaan kompensasi yang ada.

Analisis:

Pada kalimat 1, kalimat setelah したがって adalah berupa akibat atau hasil dari sebab yang tertulis de depannya. Pada kalimat sebelumnya tertulis bahwa untuk kasus si penanya, penanya tidak perlu melakukan pembayaran pajak penghasilan untuk Jepang, karena basis pekerjaan penanya berada di Thailand. Karena adanya 'sebab', maka kalimat berikutnya dapat menggunakan konjungsi したがって、karena kalimat setelah したがって adalah kalimat yang mengandung makna akibat (akibatnya adalah penanya tidak perlu membayar pajak penghasilan di Jepang). 
Q ただ「うるさい」というだけでは駄目なのですね。それで実際に測定してみたところ、 騒音は 50 ホンを超えていました。これで売買契約は解除できないでしょうか。

'Tanya: Ternyata dengan mengatakan "berisik" saja tidak cukup ya. Setelah ditelusuri, ternyata tingkat kebisingan melampaui 50 fon. Apakah dengan kejadian ini kontrak jual beli dapat dibatalkan?'

A 売買契約を解除して今まで支払った売買代金の返還を求められるのは民法 570 条、 売買の目的物に隠れた瑕疵がある場合のは民法 566 条の規定を準用します。同条項は

「買主がこれを知らないときは、このために契約の目的が達せられない場合、契約の解 除をなすことができる」と規定しています。

したがって、マンションがその騒音によって生活できないような状態であれば、あなた は売買契約を解除することができます。

'Jawab: Jika ingin membatalkan kontrak jual beli dan ingin uang yang dibayar selama ini untuk kontrak jual beli dikembalikan, maka menggunakan pasal 570 hukum perdata tentang kecacatan tersembunyi yang terdapat pada barang, yang bersumber pada pasal 566 hukum perdata. Pasal tersebut berbunyi "Kontrak dapat dibatalkan dikarenakan pembeli tidak tahu mengenai kecacatan tersebut sehingga menyebabkan tujuan pembelian tidak tercapai”. Oleh sebab itu, jika apartemen tersebut dalam kondisi ribut sehingga menyebabkan kehidupan sehari-hari terganggu maka anda dapat membatalkan kontrak jual beli'

Analisis:

Pada kalimat 2 konjungsi したがって dapat digunakan karena kalimat sebelum したがって adalah kalimat kalimat yang berupa sebab. Kalimat tersebut menyatakan bahwa karena pada pasal 566 hukum perdata menyatakan bahwa kontrak dapat dibatalkan dikarenakan pembeli tidak tahu mengenai kecacatan tersebut sehingga menyebabkan tujuan pembelian tidak tercapai. Karena adanya alas an tersebut, maka konjungsi したがって dapat digunakan karena kalimat setelah konjungsi したがって adalah kalimat yang berupa akibat yaitu bahwa si pembeli apartemen dapat membatalkan kontrak jual beli karena kondisi apatemen yang rebut sehingga menyebabkan kehidupan sehari-hari terganggu.

魏研究員は「20 世紀に米国が月探査を行った際、カメラほどの大きいさの望遠鏡を月面 に持ち込んだことがあるが、その望遠鏡はとても小さく、技術的にも現在ほど進んだも のではなかった。その後、40-50 年間にわたって、天体望遠鏡を月に持ち込んだことは ない。したがって、中国の嫦娥 3 号が搭載する『紫外望遠鏡』が、月面から天体観測を 行えば『世界初』ということができるだろう」と述べる。

'Para peneliti mengatakan "Di abad 20 teropong bintang sebesar ukuran kamera pernah dibawa ke bulan oleh orang Amerika yang sedang mengadakan penelitian di bulan. Teropong bintang itu ukurannya sangat kecil, dan secara teknologi pun tidak semaju seperti sekarang. 40 sampai 50 tahun sesudahnya pun tidak pernah ada lagi teropong bintang yang dibawa ke bulan. Oleh sebab itu, jika pesawat nomor 3 China membawa "teropong bintang Murasaki Gai”, dan mengadakan peneropongan bintang dari bulan, maka dapat dikatakan sebagai "Yang pertama di dunia"”

Analisis:

Pada kalimat 3 konjungsi したがって juga dapat digunakan karena kalimat sebelum konjungsi したがって adalah kalimat yang berupa sebab atau alasan dan kalimat setelah konjungsi したが っ adalah kalimat yang berupa akibat (karena selama 40 sampai 50 tahun setelah teropong bintang seukuran kamera dibawa ke bulan , tidak pernah ada lagi teropong bintang yang dibawa ke bulan,maka jika pesawat nomor 3 China membawa teropong bintang "Murasaki Gai"dan mengadakan peneropongan ke bulan, maka dapat dikatakan sebagai "Yang Pertama di Dunia") 
Analisis fungsi ゆえに

$$
\begin{aligned}
& \text { そのルノー } 4 \text { オーナーのための国際ミーティングが開かれることを知った。「 } 4 \mathrm{~L} \text { アンテル } \\
& \text { ナシオナル (インターナショナル)」と題されたイベントは、今年で第 } 2 \text { 回だ。ルノー愛 } \\
& \text { 好者のイベントは、なかなか把握しにくい。なぜなら数年まえからパリの古典者見本市「レ } \\
& \text { トロモビル」から、ルノーが撤退してしまったからである。ゆえに、これは貴重なチャンス } \\
& \text { だ。ボクはミーティングが開催されるというフランス中部ロワール・エ・シェール県のトゥ } \\
& \text { ネーという村に向かった。 }
\end{aligned}
$$

'Saya mengetahui bahwa ada pertemuan internasional untuk untuk para pemilik mobil Renault 4. Acara yang bertajuk "4 L International” tersebut merupakan acara yang ke dua kalinya yang diadakan pada tahun ini. Acara bagi pecinta mobil Renault sangat jarang. Hal itu dikarenakan peristiwa penarikan Renault dari Pameran Contoh Mobil Kuno "Retro Mobil” yang diadakan di Paris beberapa tahun yang lalu. Oleh karena itu, ini merupakan kesempatan langka. Saya akan berangkat ke desa Toune yang berada di propinsi Loir Et Cher、 Perancis Tengah, tempat diadakannya pertemuan bagi pecinta mobil Renault.'

Analisis:

Pada kalimat 1 konjungsi ゆえに dapat digunakan karena kalimat sebelum ゆえに adalah kalimat yang menyatakan sebab ada acara pertemuan internasional untuk 4 orang pemilik mobil Renault, dan kelimat setelah ゆえに adalah kalimat yang berupa akibat, bahwa setelah mengetahui hal tersebut maka penulis artikel tersebut (Tn. Gregory) bermaksud untuk berangkat ke desa Toune yang berada di propinsi Loir Et Cher, Perancis Tengah tempat diadakannya pertemuan tersebut.

大丸新長田店（神戸市市長田区）にある「想いやり生乳」は、一切ってを加えない生の 搾りたて。加熱殺菌もしない。ゆえに、牛乳ではなく生乳を名乗る。週 1 回の入荷で数 量限定だ。

'Susu Murni “Omoiyari” yang berada di took Daimaru Shinnagata (Kota Kobe, Nagata) merupakan susu peras yang benar-benar murni dan tidak dilakukan pembunuhan kuman. Oleh karena itu dinamai Susu Murni, bukan susu. "Susu Murni Omoiyari” ini dalam satu minggu hanya memproduksi satu kali sehingga jumlahnya terbatas’

Analisis :

Pada kalimat 2 konjungsi ゆえに dapat digunakan karena sebelum konjungsi ゆえに adalah kalimat yang berupa sebab, yaitu susu murni “Omoiyari” merupakan susu peras yang benar-benar murni dan tidak dilakukan pembunuhan kuman terhadap susu tersebut. Maka kalimat setelah konjungsi ゆえに adalah kalimat yang berupa akibat bahwa oleh sebab itu susu tersebut dinamai "Susu Murni”, bukan “susu”.

その療養所を前身とする富士見高原病院は、地域医療の中核病院として信頼されている。 だが、敷地の中心に存在する旧富士病棟本館を保存するため、避けて建物を配置してき た。ゆえに、使い勝手の悪い病院になってしまった。住民から求められる高度医療を維 持し、近代化にと敷地中心への新病棟建設計画を立てた。病院独自での保存は困難であ る。計画では、富士病棟を 2013 年 3 月に解体することになったのである。

'Rumah sakit Fuji Kougen yang bertempat di kawasan tanah perawatan dokter dipercaya sebagai pusat pengobatan daerah. Tetapi pada saat pembangunan gedung rumah sakit Fuji Kougen, gedung rumah sakit yang lama tetap dipertahankan. Oleh karena itu, susunan rumah sakit ini menjadi buruk. Setelah menerima permintaan pengobatan dengan menggunakan teknologi tingkat tinggi dan permintaan untuk melakukan modernisasi maka disusunlah rencana untuk melakukan perombakan terhadap gedung rumah sakit tersebut yang akan dimulai pada bulan Maret tahun 2013.' 
Analisis:

Pada kalimat 3 konjungsi ゆえに juga dapat digunakan karena kalimat sebelum ゆえに adalah kalimat yang berupa sebab yaitu bahwa pada saat membangun gedung rumah sakit baru (Rumah Sakit Fuji Kougen), gedung rumah sakit yang lama tetap dipertahankan. Kemudian kalimat setelah konjungsi ゆえに adalah kalimat yang berupa akibat yaitu susunan rumah sakit tersebut menjadi buruk, sehingga ada permintaan untuk melakukan perombakan rumah sakit yang akan dimulai pada bulan Maret tahun 2013.

Tabel 1 Analisis Konjungsi したがって dan ゆえに

\begin{tabular}{|c|c|c|}
\hline \multirow{2}{*}{ No.Data } & \multicolumn{2}{|c|}{ Kalimat setelah konjungsi } \\
\hline & したがって & ゆえに \\
\hline 1 & $\begin{array}{l}\text { したがって、本社は源泉徵収をしませ } \\
\text { ん。ただし、この差額補てん分を含めて } \\
\text { タイの所得税を支払う必要があります。 } \\
\text { 'Oleh sebab itu, perusahaan pusat tidak akan } \\
\text { melakukan penarikan pembayaran. Akan } \\
\text { tetapi, anda harus membayar pajak } \\
\text { penghasilan di Thailand beserta dengan } \\
\text { perbedaan kompensasi yang ada.’ }\end{array}$ & $\begin{array}{l}\text { ゆえに、これは貴重なチャンスだ。ボクはミ } \\
\text { ーティングが開催されるというフランス中部 } \\
\text { ロワール・エ・シェール県のトゥネーという } \\
\text { 村に向かった。 } \\
\text { Oleh karena itu, ini merupakan kesempatan } \\
\text { langka. Saya akan berangkat ke desa Toune yang } \\
\text { berada di propinsi Loir Et Cher、 Perancis Tengah, } \\
\text { tempat diadakannya pertemuan bagi pecinta mobil } \\
\text { Renault.' }\end{array}$ \\
\hline 2 & $\begin{array}{l}\text { したがって、マンションがその騷音によ } \\
\text { つ生活できないような状態であれば、 } \\
\text { あなたは売買契約を解除することができ } \\
\text { ます。 } \\
\text { ‘Oleh sebab itu, jika apartemen tersebut } \\
\text { dalam kondisi ribut sehingga menyebabkan } \\
\text { kehidupan sehari-hari terganggu maka anda } \\
\text { dapat membatalkan kontrak jual beli’ }\end{array}$ & $\begin{array}{l}\text { ゆえに、牛乳ではなく生乳を名乗る。週 } 1 \text { 回 } \\
\text { の入荷で数量限定だ。 } \\
\text { ‘Oleh karena itu dinamai Susu Murni, bukan susu. } \\
\text { “Susu Murni Omoiyari” ini dalam satu minggu } \\
\text { hanya memproduksi satu kali sehingga jumlahnya } \\
\text { terbatas’ }\end{array}$ \\
\hline 3 & $\begin{array}{l}\text { したがって、中国の嫦娥 } 3 \text { 号が搭載する } \\
\text { 『紫外望遠鏡』が、月面から天体観測を } \\
\text { 行えば『世界初』ということができるだ } \\
\text { ろう」と述べる。 } \\
\text { ‘Oleh sebab itu, jika pesawat nomor } 3 \text { China } \\
\text { membawa “teropong bintang Murasaki Gai”, } \\
\text { dan mengadakan peneropongan bintang dari } \\
\text { bulan, maka dapat dikatakan sebagai “Yang } \\
\text { pertama di dunia”’ }\end{array}$ & $\begin{array}{l}\text { ゆえに、使い勝手の悪い病院になってしまっ } \\
\text { た。住民から求められる高度医療を維持し、 } \\
\text { 近代化にと敷地中心への新病棟建設計画を立 } \\
\text { てた。病院独自での保存は困難である。計画 } \\
\text { では、富士病棟を } 2013 \text { 年 } 3 \text { 月に解体する } \\
\text { ことになったのである。 } \\
\text { 'Oleh karena itu, susunan rumah sakit ini menjadi } \\
\text { buruk.. Setelah menerima permintaan pengobatan } \\
\text { dengan menggunakan teknologi tingkat tinggi dan } \\
\text { permintaan untuk melakukan modernisasi maka } \\
\text { disusunlah rencana untuk melakukan perombakan } \\
\text { terhadap gedung rumah sakit tersebut yang akan } \\
\text { dimulai pada bulan Maret tahun 2013.’ }\end{array}$ \\
\hline
\end{tabular}

Setelah melihat Tabel 1 di atas dapat disimpulkan bahwa kalimat setelah konjungsi したがっ $\tau$ hanya berupa hasil atau akibat yang ditimbulkan dari kalimat sebelumnya, sedangkan kalimat setelah konjungsi ゆえに merupakan kalimat yang memiliki unsur keinginan seperti pada kalimat 1 (Tn. Gregory bermaksud untuk pergi ke desa Toune yang terletak di propinsi Loir et Cher, Perancis Tengah tempat diadakannya pertemuan bagi pecinta mobil Renault) , pada kalimat 2 dimana ada keinginan untuk menjaga kualitas dari Susu Murni “Omoiyari” maka produsen susu tersebut hanya memproduksi satu kali dalam satu minggu dan pada kalimat 3 dimana ada keinginan untuk melakukan perombakan terhadap gedung rumah sakit yang rencananya akan dimulai pada bulan Maret tahun 2013. 


\section{PENUTUP}

Selain konjungsi したがって dan ゆえに, sebenarnya masih banyak lagi konjungsi lain dalam bahasa Jepang yang memiliki makna yang sama tetapi berbeda dalam penggunaannya dan dapat dijadikan bahan untuk penelitian berikutnya. Penulis menyadari bahwa masih banyak kekurangan dalam penelitian ini dan penulis mengharapkan masukan dari pembaca setelah membaca artikel ini.

\section{DAFTAR PUSTAKA}

AJALT (1991). Reading Japanese Financial Newspaper. Japan: Kodansha International

Katayama, Tomoo (1995). News Nihongo Read and Listening to the News In Japanese. Japan: ALC

一，(2010) 結核療養の証人・病棟の保存を. 朝日新聞社， 3 April 2010. Diunduh dari $<$ http://mytown.asahi.com/nagano/news.php?k id=21000191004030003>

人民網日本語版. (2010). 中国 世界初、月面からの天体観測を実施一. 朝日新聞社, 24 Agustus 2010. Diunduh dari <http://www.asahi.com/international/jinmin/TKY201008240306.html>

大矢アキオ, (2010) ルノー4の大運動会 前編, 朝日新聞社, 23 Juli 2010 Diunduh dari $<$ http://www.asahi.com/car/italycolumn/TKY201007220308.html>

多田雄司，(2010)，海外赴任中の税金、どの国へ払う？ 朝日新聞社，18 September 2010. Diunduh dari <http://www.asahi.com/housing/soudan/TKY201009170226.html>

田中峯子. (2010), マンションの防音性能. 朝日新聞社, 28 Agustus 2010. Diunduh dari $<$ http://www.asahi.com/housing/soudan/TKY201008270201.html $>$

岡井哲弥，(2010) 搾りたて生乳 加熱殺菌ゼロ ・大丸新長田店, 朝日新聞社, 22 Juni 2010. Diunduh dari <http://www.asahi.com/food/column/depa/OSK201006220055.html>

\section{RIWAYAT PENULIS}

Felicia lahir di kota Jakarta pada 17 September 1983.Penulis menamatkan pendidikan S1 di Universitas Bina Nusantara dalam bidang ilmu Sastra Jepang pada tahun 2005. Saat ini bekerja sebagai dosen di Universitas Bina Nusantara. 